\title{
Increased serum pancreatitis associated protein (PAP) concentration after longterm alcohol consumption: further evidence for regular subclinical pancreatic damage after heavy drinking?
}

\author{
I Nordback, M Jaakkola, J L Iovanna, J C Dagorn
}

\begin{abstract}
It has been shown recently that longterm but not short term heavy drinking of alcohol frequently results in increased serum activities of pancreatic enzymes suggesting subclinical pancreatic injury. Serum pancreatitis associated protein (PAP) is a novel protein, whose synthesis in the acinar cells and release into serum is specifically induced by acute pancreatic damage. This study was performed to further characterise the alcohol induced subclinical pancreatic injury by using serum PAP measurements. Three groups were studied: (1) control group $(n=25)$, (2) short term drinking group $(n=20)$, who consumed $2 \cdot 0 \mathrm{~g}$ of ethanol per $\mathrm{kg}$ body weight during four hours, and (3) longterm drinking group $(n=32)$, who were admitted to withdrawal clinic after a median 30 months heavy drinking period. Serum PAP concentration was low in the control group (8 (5 to 12$) \mu \mathrm{g} / \mathrm{l}$, geometric mean (95\% confidence intervals)). In the short term drinking group serum PAP was in the range of the control group values during 56 hours after drinking. Longterm drinking induced at least a 10fold increase in serum PAP, the highest concentrations being seen on day 2 after drinking had ended (106 (61 to 184) $\mu \mathrm{g} / \mathrm{l}$ ). The patients did not develop abdominal symptoms, increased blood white cell count, or increased serum $C$ reactive protein concentration. These results further support the suggestion that heavy longterm drinking often induces subclinical pancreatic damage, but not clinical pancreatitis.
\end{abstract}

(Gut 1995; 36: 117-120)

Keywords: alcohol consumption, serum activities, pancreatic injury, PAP concentration.

Pancreatitis associated protein (PAP) is a recently discovered pancreatic exocrinic secretory protein that is not secreted in detectable concentrations in pancreatic juice in normal conditions but whose expression is strongly induced in experimental acute pancreatitis. ${ }^{1}$ The induction of PAP synthesis in the pancreas has always been seen during acute pancreatitis with all models of experimental pancreatitis studied so far. ${ }^{1}$ Also, PAP has an ability to induce bacterial aggregation in vitro. ${ }^{2}$ PAP can thus perhaps be characterised as a pancreatic 'acute phase protein', being probably not so important in the pathogenesis of acute pancreatitis, but perhaps representing endogenous defence mechanisms. ${ }^{2}$ Although PAP is secreted in zymogen granules from the acinar cells into the pancreatic juice, PAP also leaks from the pancreas into serum in acute pancreatitis, ${ }^{12}$ as other secretory proteins do. Increased serum PAP concentrations are detected in experimental pancreatitis and clinical acute pancreatitis whereas PAP is scarcely detectable in the serum of healthy subjects. ${ }^{3}$ Furthermore, the serum PAP concentrations correlate well with the clinical severity of acute pancreatitis. ${ }^{4}$ It is not known, however, if clinical pancreatitis is required before PAP increases in serum, or if subclinical pancreas irritation also results in increased serum PAP concentrations. Recently, we have shown that longterm ${ }^{5}$ but not short term $^{6}$ drinking of alcohol frequently results in increased serum activities of pancreatic enzymes suggesting subclinical pancreatic injury. This study was designed to find out if short term and longterm heavy drinking induce increased concentrations of PAP in serum.

\section{Methods}

\section{CONTROL GROUP}

Serum samples were collected from 25 healthy adult volunteers (age 22-26 years) after a six hour fast and stored at $-70^{\circ} \mathrm{C}$ for later assay of PAP to create a local reference material for the study (group A). These healthy adults had not had any alcohol for at least a week. Their previous alcohol consumption had been minimal. They were not aware of any diseases and they were not taking any drugs.

SHORT TERM DRINKING GROUP

The short term drinking group (group B) consisted of 20 healthy adult volunteers $(10$ men and 10 women). The age varied between 22 and 26 years (median 24). They had no current physical problems and they had never 
suffered from abdominal complaints. All 20 subjects in this group drank during a four hour period $2 \cdot 0 \mathrm{~g}$ of ethanol per $\mathrm{kg}$ of body weight as $10 \%$ solution in berry juice. Venous blood samples were taken both before and $6,18,30$, and 56 hours after starting to drink. There was a six hour fast before the blood samples were taken. The peak blood ethanol concentration was $0 \cdot 16 \%$ at six hours. Blood white cell count was measured immediately, and serum was separated by centrifugation and stored at $-70^{\circ} \mathrm{C}$ for later assays.

\section{LONGTERM DRINKING GROUP}

The longterm drinking group (group $\mathrm{C}$ ) consisted of 32 adults, who were admitted to a detoxication unit for a seven day period, to overcome the withdrawal period after heavy and longterm drinking. The treatment consisted of psychotherapy and benzodiazepine treatment in 26 patients and psychotherapy without drugs in six patients. Twenty five were men and seven women. The median age was 41 years (range 26-68). None of the 32 patients currently had any abdominal symptoms, or other physical problems. None of the patients were diabetic, none had diarrhoea, and none had suffered from regular abdominal pains. None had any alcohol during this treatment period.

Four patients in group $\mathrm{C}$ had a history of previous acute episode of pancreatitis. These patients had been fully recovered without complications for a minimum of three months before the study. Each patient had abdominal ultrasonography. Four patients had pancreatic calcifications, one had a pancreatic pseudocyst, and two had both calcifications and a pseudocyst. Thus a total of nine patients had previously had pancreatitis, confirmed either by clinical history or by ultrasonographic pancreatic morphology. These patients did not differ in any other way from the remaining patients. Eighteen patients had increased echogenity of the liver suggestive of lipodystrophy or cirrhosis. No other abdominal abnormality was detected.

The study patients had been heavy drinkers for many years with intermittent abstinence periods. The duration of their current high alcohol consumption was 30 (2 to 58) months (geometric mean (95\% confidence limits). Each patient was interviewed by an investigator who did not participate in the withdrawal treatment. A standardised questionnaire was used to evaluate daily alcohol consumption in grams of $100 \%$ ethanol during the past two months. Two months was the longest period

TABLE I Serum PAP concentration, CRP concentration, p-amylase activity, and lipase activity in 20 healthy volunteers after high dose short term alcohol consumption (group B)

\begin{tabular}{cclll}
\hline Time $(h)$ & $P A P(\mu g /)$ & $C R P(m g /)$ & $p$-Amylase $(U /)$ & Lipase $(U /)$ \\
\hline 0 & $7(4$ to 11$)$ & $2(2$ to 3$)$ & $97(84$ to 111$)$ & $125(101$ to 155$)$ \\
6 & $8(5$ to 13$)$ & $3(2$ to 4$)$ & $94(82$ to 109$)$ & $131(107$ to 161$)$ \\
18 & $9(5$ to 15$)$ & $3(2$ to 4$)$ & $95(81$ to 110$)$ & $120(98$ to 147$)$ \\
30 & $9(6$ to 13$)$ & $2(2$ to 3$)$ & $91(79$ to 106$)$ & $104(85$ to 126$)$ \\
56 & $10(6 \text { to } 16)^{\star}$ & $2(2$ to 3$)$ & $89(77$ to 104$)$ & $106(84 \text { to } 133)^{\star}$ \\
\hline
\end{tabular}

Data are shown as geometric mean $\left(95 \%\right.$ confidence intervals). ${ }^{\star} \mathrm{p}<0.05$ compared with baseline value $(h=0)$. the patients could recall their alcohol consumption. The daily consumption during the two months varied between 120 and $500 \mathrm{~g}$ (median $260 \mathrm{~g}$ ).

Venous blood samples were taken after a six hour fast on the day of admission (day 1) and on day 2,4 , and 7 . White cell count was measured immediately, and serum was separated by centrifugation and stored at $-70^{\circ} \mathrm{C}$ for later assays.

Serum pancreatic isoamylase ( $\mathrm{p}$-amylase) activity, lipase activity, $\mathrm{C}$ reactive protein (CRP) concentration, and PAP concentration were determined from each serum sample. P-amylase activity was determined on a Hitachi 704 autoanalyser (Hitachi Co, Japan) with a commercial kit (cat no 979759, Boehringer, Germany). Serum lipase activity was determined on a Kodak Ektachem 700 autoanalyser (Kodak Co, NY). Blood total white cell count was measured on a Coulter S Plus IV counter (Coulter Electronics, Hileah, USA). Serum C reactive protein concentration was determined on a Hitachi 704 autoanalyser (Hitachi Co, Japan). Serum PAP concentration was determined by a competitive enzyme linked immunosorbent assay (ELISA), using a nonspecific rabbit antiserum to human PAP. ${ }^{7} 8$

Values are given to each group as the geometric mean of the individual data $(95 \%$ confidence intervals $(\mathrm{CI})$ ). Analysis of variance (ANOVA) was used to calculate the statistical significance of the differences between groups, after logarithmic transformation when comparing skewly distributed populations. Linear regression analysis was used to calculate correlations. The study protocols were approved by the ethical committee of Tampere University Hospital.

\section{Results}

In the control group (group A) the serum PAP concentration was 8 ( 5 to 12 ) $\mu \mathrm{g} / \mathrm{l}$. In the short term drinking group (group B) the serum PAP remained low, although a statistically significant increase from the baseline value was seen at 56 hours (Table I). Serum CRP concentration, p-amylase activity, and lipase activity did not increase when compared with the baseline value, or with the control group (Table I). By contrast, lipase activity showed a small but statistically significant decrease at 56 hours (Table I).

In the longterm drinking group (group C) serum PAP concentrations were about 10 -fold higher than in the control group (group A) or in the short term drinking group (group B) (Table II). All 32 longterm heavy drinkers had a peak serum PAP concentration over $20 \mu \mathrm{g} / 1$, and 15 of $32(47 \%)$ had a peak serum PAP concentration over $100 \mu \mathrm{g} / \mathrm{l}$.

In group $\mathrm{C}$ the serum PAP concentration was increased both in the nine patients with previous pancreatitis and the 23 patients without evidence of previous pancreatitis. The patients with previous pancreatitis had an increase in PAP concentrations greater than the other patients (Table III). The patients with ultrasonographic liver changes did not 
TABLE II Serum PAP concentration, CRP concentration, $p$-amylase activity, and lipase activity during seven day withdrawal period in 32 asymptomatic patients after a median of 30 months high dose alcohol consumption (group C)

\begin{tabular}{lclcl}
\hline Day & $P A P(\mu g /)$ & $C R P(m g /)$ & $p$-Amylase $(U / l)$ & Lipase $(U / l)$ \\
\hline 1 & $81(51$ to 130$)$ & $4(2$ to 7$)$ & $81(67$ to 97$)$ & $200(147$ to 271$)$ \\
2 & $106(61$ to 184$)$ & $5(3$ to 8$)$ & $91(78 \text { to } 106)^{\star}$ & $265(195 \text { to } 361)^{\star \star \star}$ \\
4 & $63(39$ to 99$)$ & $3(2$ to 5$)$ & $128(108 \text { to } 151)^{\star \star \star}$ & $288(206 \text { to } 423)^{\star \star \star}$ \\
7 & $68(43$ to 107$)$ & $5(4$ to 7$)$ & $133(113 \text { to } 152)^{\star \star \star}$ & $261(198 \text { to } 343)^{\star \star}$ \\
\hline
\end{tabular}

Data are shown as geometric mean $\left(95 \%\right.$ confidence intervals). ${ }^{\star} \mathrm{p}<0.05$ compared with baseline value; ${ }^{\star \star} p<0.01$ compared with baseline value; ${ }^{\star \star} p<0.001$ compared with baseline value

differ from the remaining patients with regard to serum PAP concentrations.

In group $\mathrm{C}$ the serum PAP concentration did not correlate either with the ethanol consumption during the preceding two months or with the ethanol consumption during the preceding week.

In group $\mathrm{C}$ the increased serum PAP concentration did not correlate with the serum CRP concentration that remained at the control value.

In group $C$ the serum $p$-amylase and lipase activities significantly increased (Table II). The serum PAP concentration correlated significantly with the serum lipase activity on day 2 (correlation coefficient $r=0.37$, $\mathrm{p}=0.047)$ and on day $4(r=0.56, \mathrm{p}=0.002)$, but not on day 1 or on day 7 . The serum PAP concentration did not correlate with serum p-amylase activity at any time.

\section{Discussion}

Acute pancreatitis is a common disorder, resulting in about 70 cases being admitted to hospital per year for every 100000 inhabitants in Finland. ${ }^{9}$ Alcohol is the cause of acute pancreatitis in Finland in about $70 \%$ of cases. ${ }^{10}$ Despite intensive research, the pathogenesis of acute alcoholic pancreatitis has remained obscure. Hypotheses focusing on ductal or ductular obstruction, with or without concomitant pancreatic hypersecretion have been popular. ${ }^{11} 12$ Others ${ }^{13}$ support the hypothesis of a direct toxic effect on the pancreas of ethanol, or its metabolites, based on the many metabolic changes seen in the pancreas after alcohol consumption.

We have previously studied the dose relations between ethanol consumption and the occurrence and severity of acute pancreatic injury. We have shown that firstly, the severity of the first episode of clinical acute pancreatitis (hospital stay, complications, serum $\mathrm{C}$ reactive protein concentration, and Ranson signs), ${ }^{14}$ and secondly, the incidence and severity of pancreatitis in a population ${ }^{9} 11$ are dose dependent on the alcohol consumption. These findings may be considered as supporting the toxic metabolic hypothesis. We have also suggested that the appearance of subclinical pancreatic injury may be dependent on the length of the period of high dose alcohol consumption, as based on serum pancreatic enzyme activities. ${ }^{56}$ Serum PAP concentrations were monitored to further characterise the suggested subclinical pancreatic injury after alcohol consumption.
In acute experimental pancreatitis, protein composition of the exocrine secretion changes considerably. The secretion of many proteins, including enzymes and proenzymes, is strongly reduced, ${ }^{15}$ whereas a few proteins are secreted in higher amounts. ${ }^{21516}$ The most dramatic increase was reported for the secretion of a lectin related protein called PAP.15 The increased PAP secretion is the consequence of increased de novo synthesis that is induced by acute tissue injury in the pancreas but not in any other organs studied. ${ }^{12}$ PAP also leaks in circulation during acute pancreatitis together with the other pancreatic secretory proteins. ${ }^{1-3}$ In contrast with PAP, the synthesis of enzymes and proenzymes sharply decreases, explaining the fall in serum enzyme activities, and the lack of correlation between the serum enzyme and PAP measurements. Increased serum PAP concentrations have been detected only in association with acute pancreatitis, or with an acute exacerbation of chronic pancreatitis, but not in healthy subjects or in other abdominal diseases. ${ }^{3}$ Thus increased PAP concentration in serum has been thought to reflect acute pancreatic injury.

In this study serum PAP concentration was just within the limits of the sensitivity of the assay in healthy subjects, in accordance with previous studies. ${ }^{3}$ In a previous study ${ }^{7} 10 \mu \mathrm{g} / 1$ has been suggested as an upper normal range for serum PAP. In this study, although the geometric mean value of serum PAP in the control group (group A) was $8 \mu \mathrm{g} / \mathrm{l}$, the upper limit of $95 \%$ CI was at $12 \mu \mathrm{g} / \mathrm{l}$ and some values were between 12 and $20 \mu \mathrm{g} / \mathrm{l}$. For this study, the upper limit of the normal range was therefore set at $20 \mu \mathrm{g} / \mathrm{l}$. Short term heavy drinking induced a slight increase in serum PAP concentration from the baseline value and a slight decrease in serum lipase activity. These changes are in agreement with those seen in the rat pancreatitis. ${ }^{21516}$ Because the increase in serum PAP concentration was small, however, and the concentrations were still within the range of the control group, the significance of this finding may be limited.

In all 32 patients with longterm heavy drinking serum PAP was well above that threshold. On average, longterm heavy drinking induced a 10-fold increase in serum PAP concentrations, about half of the heavy drinkers showing a peak serum PAP concentration over 100 $\mu \mathrm{g} / \mathrm{l}$. Such concentrations have previously been seen only in clinical acute oedematous pancreatitis. ${ }^{17}$ Longterm heavy drinking also induced a small, albeit statistically significant

TABLE III Serum PAP concentrations during seven day withdrawal period in 32 patients after a median of 30 months high dose alcohol consumption, of whom nine had previously had pancreatitis and 23 had not a history or ultrasonographic morphology of previous pancreatitis

\begin{tabular}{lll}
\hline Day & $\begin{array}{l}\text { No previous } \\
\text { pancreatitis }(n=23)\end{array}$ & $\begin{array}{l}\text { Previous } \\
\text { pancreatitis }(n=9)\end{array}$ \\
\hline 1 & $63(35$ to 114$)$ & $152(71$ to 323$)$ \\
2 & $83(43$ to 158$)$ & $185(58$ to 588$)$ \\
4 & $51(33$ to 79$)$ & $104(27$ to 408$)$ \\
7 & $49(30 \text { to } 80)^{\star}$ & $141(51 \text { to } 370)^{\star}$
\end{tabular}

Data are shown as geometric mean $(95 \%$ confidence intervals). ${ }^{\star} \mathrm{p}<0.05$ between groups. 
increase in serum p-amylase and lipase activities. Serum PAP concentration poorly correlated with serum p-amylase and lipase activities, as expected, because of the change in the pattern of gene expression. ${ }^{21516}$ The increased serum PAP after longterm heavy drinking might suggest acute pancreatic injury taking place after such alcohol consumption. ${ }^{6}$

None of the patients developed clinical acute pancreatitis. Therefore the injury, if present, was subclinical. Because it is unethical to obtain pancreatic biopsy specimens from an asymptomatic subject by any method currently available, the presence of a subclinical pancreatic injury can never be fully proved in a human. Increased p-amylase may be found in patients with duct obstruction, but without clinical evidence of acute pancreatitis. Therefore, it is possible that an increase in PAP concentration could also be found. P-amylase and PAP are both synthesised in pancreatic acinar cells ${ }^{3}$ but in contrast with p-amylase, PAP synthesis does not take place under normal conditions. If increased PAP is also found in duct obstruction then induction of PAP synthesis is an acinar cell response to the outflow obstruction. This change is not necessarily associated with clinical pancreatitis, but at the cellular biochemical level the response is similar to that is seen in acinar cells trying to survive acute pancreatitis. ${ }^{315}$

In theory, serum PAP might be secreted from another source. Induction of the PAP gene in other organs, however, has not been reported before. ${ }^{12}$ Furthermore, decreased elimination of PAP might partly explain increased serum PAP concentrations. The elimination of PAP and the half life in serum are not well known. In acute pancreatitis, at least part of the PAP is hydrolysed, the $N$-terminal but not the whole molecule being secreted in urine. ${ }^{18}$ In fact, serum PAP may be somewhat increased in pancreatitis patients with severe renal insufficiency, compared with those with normal renal function. ${ }^{19}$ In this study none had impaired renal function judged by serum creatinine and potassium concentration. Also, if PAP is eliminated by the liver, the PAP increase should be enhanced by impaired liver function. PAP did not correlate with the liver function tests. It is possible, however, that any currently unidentified mechanism of elimination of PAP, when impaired, may modify the observed PAP concentrations in serum. It should be remembered that the appearance of any measurable PAP in serum is not primarily dependent on the elimination, but on de novo synthesis, which does not take place under normal conditions. This synthesis has been shown only in the pancreatic acinar cells. Therefore the appearance of measurable PAP in serum after longterm heavy alcohol consumption most probably represents the pancreatic acinar cell response. Because this response is similar to that seen in clinical acute pancreatitis, it is suggested that longterm heavy drinking may often induce subclinical acinar cell injury.

The authors acknowledge financial support for this study from The Paulo Foundation, Helsinki, Finland.

1 Keim V, Iovanna J, Rohr G. Usadel KH, Dagorn JC. Characterization of a rat pancreatic secretory protein associated with pancreatitis. Gastroenterology 1991; 100: 775-82.

2 Iovanna J, Orelle B, Keim V, Dagorn JC. Messenger RNA sequence and expression of rat pancreatitis associated protein, a lectin-related protein overexpressed during protein, a lectin-related protein overexpressed during acute experir

3 Orelle B, Keim V, Masciotra L, Dagorn JC, Iovanna J. Human pancreatitis-associated protein. Messenger RNA cloning and expression in pancreatic diseases. 7 Clin Invest 1992; 90: 2284-91.

4 Iovanna J, Keim V, Nordback I, Levy C, Montalto G, Camarena J, et al. Serum concentrations of 'pancreatitis associated protein' (PAP) correlate with the severity of acute pancreatitis. Gastroenterology 1993; 104: A309.

5 Jaakkola M, Sillanaukee P, Suomalainen H, Koivula T, aakkola $M$, Sillanaukee P, Suomalainen H, Koivula T,
Nordback I. Effect of a high dose of ethanol on serum Nordback I. Effect of a high dose of ethanol on serum
pancreatic enzymes in young healthy adults. $A m \mathcal{F}$ pancreatic enzymes in youn

6 Jaakkola M, Frey T, Sillanaukee P, Suomalainen H, Koivula $T$, Nordback I. Acute pancreatic injury in asymptomatic individuals after long-term heavy drinking. Hepatogastroenterology (in press)

7 Keim V, Iovanna JI, Rohr G, Usadel K, Dagorn J-C. Characterization of a pancreatic secretory protein associated with pancreatitis. Gastroenterology 1991; 100: 775-82.

8 Keim V, Iovanna JI, Orelle B, Verdier J-M, Büsing M, Hopt $\mathrm{U}$, et al. A novel exocrine protein associated with pancreas transplantations in humans. Gastroenterology 1992; 103: transplan

9 Jaakkola M, Nordback I. Pancreatitis in Finland between 1970 and 1989. Gut 1993; 34: 1255-60.

10 Jaakkola M, Nordback I, Karjalainen J, Oksanen H, Lindholm TS. Changes in etiology of acute pancreatitis. Report of 2005 cases between 1972 and 1990. Surg Res Comm 1993; 14: 307-11.

1 Singh $M$, Simsek H. Ethanol and the pancreas. Current status. Gastroenterology 1990; 98: 1051-62.

12 Wilson JS, Korsten MA, Pirola RC. Alcohol-induced pancreatic injury (part 1). Unexplained features and ductular theories of pathogenesis. Int $\mathcal{F}$ Pancreatol 1989; 4: 109-25.

13 Dreiling DA Bogenesis. Int Pancreatol 1989, 4: 109-25. pathogenesis of alcoholic pancreatitis. Alcohol Clin Exp Res pathogenesis of alcc

14 Jaakkola M, Sillanaukee P, Löf K, Koivula T, Nordback I. The amount of alcohol is an important determinant of the severity of acute alcoholic pancreatitis. Surgery 1994; 115: 31-8.

15 Iovanna J, Keim V, Michel R, Dagorn JC. Pancreatic gene expression is altered during acute experimental pancreatitis in the rat. Am f Physiol 1991; 261: G485-9.

16 Rouquier S, Verdier JM, Iovanna J, Dagorn JC, Giorgi D. Rat pancreatic stone protein messenger RNA. Abundant expression in mature exocrine cells, regulation by food content and sure cxity transcript. F Biol Chem 1991; 266: 786-91.

17 Iovanna JL, Keim V, Nordback I, Montalto G, Camarena J Letoublon C, et al. Serum levels of pancreatitis associated petoublon C, et al. Serum levels of pancreatitis associated protein as indicators of the course
Gastroenterology 1994; 106: 728-34.

18 Keim V, Fuchs MJ, Baum B, Lang S, Iovanna JL, Dagorn JC. Fragments of PAP (pancreatitis-associated protein) in serum and urine of patients with acute pancreatitis. Pancreas 1992; 7: 744 .

19 Keim V, Gretz N, Püttmann M, Lang S, Iovanna JL, Singer $M$, et al. Serum concentration of pancreatitis-associated protein (PAP) in patients with renal failure. Pancreas 1993; 8: 759 . 